\title{
Reproductive system of Eriocnema fulva Naudin (Melastomataceae), an endemic species of Minas Gerais state, SE Brazil
}

\author{
Andrade, PM. ${ }^{\mathrm{a} *}$, Forni-Martins, ER. ${ }^{\mathrm{b} *}$ and Martins, FR. ${ }^{\mathrm{b} *}$ \\ aPrograma de Pós-Graduação em Biologia Vegetal, Instituto de Biologia, Universidade Estadual de Campinas - UNICAMP, \\ Instituto Estadual de Florestas, Rua Espírito Santo, 495, CEP 30160-030, Belo Horizonte, MG, Brazil \\ 'Departamento de Botânica, Instituto de Biologia, Universidade Estadual de Campinas - UNICAMP, \\ CP 6109, CEP 13083-970, Campinas, SP, Brazil \\ *e-mail: priscilaandrade@epamig.br, fmartins@unicamp.br, elianafm@unicamp.br. \\ Received May 3, 2005 - Accepted March 3, 2006 - Distributed May 31, 2007
}

(With 2 figures)

\begin{abstract}
Eriocnema fulva Naudin is a perennial herb, endemic to Minas Gerais state, SE Brazil, found on humid, shaded rocky riverbanks in montane semideciduous seasonal forests. The species is threatened, but information regarding its biology is still lacking, although such information is fundamental to any management plan. We aimed to evaluate the reproductive system of Eriocnema fulva in the Jambreiro Forest (19 ${ }^{\circ} 58^{\prime}-59^{\prime} \mathrm{S}$ and $43^{\circ} 55^{\prime}-52^{\prime}$ W, 800-1100 m altitude), municipality of Nova Lima, by experiments carried out in 1997 and 1998. The flowers are white, and flowering is of the steady state type, occurring once a year from November to December. Anthers are poricidal, and pollen is the only resource for visitors. The chromosome number is $n=17$ during meiosis. The species is self-compatible, but does not produce fruits by spontaneous self-pollination or agamospermy; it requires pollen vectors and buzz pollination in order to produce fruits. Cross-pollination is the main reproductive strategy of E. fulva, and is accentuated by the small number of flowers (one or two in each plant) opened per day. Although the population studied was shaded by forest canopy, the seeds needed light to germinate. Germination ratio was lower in germination cabinet on filter paper (14\% after 30 days) than in greenhouse on soil brought from the forest (47\% after 25 days). Although the fruit is a capsule and the seeds are small, dispersion (anemochory or hydrochory) does not seem to occur at long distance, as it is the case for other Melastomataceae species with similar syndrome.
\end{abstract}

Keywords: buzz pollination, chromosome number, reproduction system, self-compatible.

\section{Sistema de reprodução de Eriocnema fulva Naudin (Melastomataceae), uma espécie endêmica do estado de Minas Gerais, sudeste do Brasil}

\begin{abstract}
Resumo
Eriocnema fulva Naudin é uma planta herbácea, perene, endêmica no estado de Minas Gerais, sendo encontrada em paredões rochosos úmidos, ao longo de riachos sombreados pela Floresta Estacional Semidecídua Montana. A espécie é ameaçada de extinção e não existem informações sobre a sua biologia, embora sejam fundamentais para um plano de manejo. Com o objetivo de avaliar o sistema de reprodução, foram feitos experimentos em 1997 e 1998 em uma

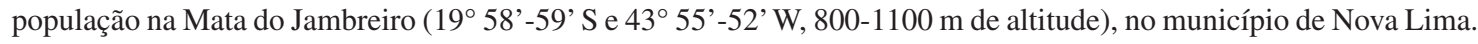
As flores são brancas e a floração é do tipo steady state, ocorrendo uma vez ao ano durante novembro e dezembro. As anteras são poricidas e o pólen é a única recompensa para os visitantes. O número cromossômico encontrado na meiose foi $n=17$. A espécie é autocompatível, não produz frutos por autopolinização espontânea nem por agamospermia, mas requer obrigatoriamente vetores de pólen e polinização vibrátil. A polinização cruzada é a principal estratégia reprodutiva de Eriocnema fulva, sendo acentuada devido ao pequeno número de flores abertas por dia, apenas uma ou duas em cada planta. Embora as populações estejam localizadas em ambientes sombreados e úmidos, as sementes precisam de luz para germinar, sendo fotoblásticas positivas. A taxa de germinação em papel de filtro na câmara de germinação foi menor (14\% após 30 dias) que em solo da floresta na casa de vegetação (47\% após 25 dias). Embora o fruto seja do tipo cápsula com sementes pequenas, a dispersão (anemocoria ou hidrocoria) parece não ocorrer a distâncias longas, como é observada em outras espécies de Melastomataceae com síndrome de dispersão semelhante.
\end{abstract}

Palavras-chave: polinização vibrátil, número cromossômico, sistema reprodutivo, autocompatível. 


\section{Introduction}

The family Melastomataceae has nearly 4500 species (Stein and Tobe, 1989), of which more than 3000 species in 107 genera occur in the Neotropics (Renner, 1989). The genus Eriocnema Naudin belongs to the tribe Miconieae (Fritsch et al., 2004) and has two species: Eriocnema fulva Naudin, 1844 and Eriocnema acaulis Triana, 1871 (Cogniaux, 1883). Both species have restricted geographical distribution, occurring as groups of plants on rocky riverbanks alongside shaded water streams in semideciduous seasonal forests in southeast Minas Gerais state, southeast Brazil.

The first collection of E. fulva was carried out by European botanical expeditions to the interior of the Brazilian countryside in the middle of the XIX century (Cogniaux, 1883). After that, it was collected by Badini (1940) in the municipalities of Ouro Preto and Sabará and by Andrade (1993) in the municipality of Nova Lima, all sites in southeast Minas Gerais state. Although it is included in the endangered species list for the state of Minas Gerais (Copam, 1997), there is no information regarding its biology or reproductive system, topics which are essential for planning conservation and management actions.

The existing literature on the Melastomataceae family describes a wide range of reproductive systems, dispersal mechanisms, and habitat preference. Species may be self-compatible or self-incompatible, and there are cases of agamospermy and hybridization between sympatric species (Renner, 1986/1987, 1989, 1990; Borges, 1990; Gross, 1993; Goldenberg, 1994; Melo and Machado, 1997, Goldenberg and Varassin, 2001). Despite these differences, Melastomataceae species show similarity in their "buzz" type pollination systems, because flowers are visited almost exclusively by bees that vibrate poricidal anthers when collecting pollen for their larvae (Vogel, 1978; Buchmann, 1983; Renner, 1984, 1989).

Interest in the study of reproductive systems is not new (Fryxell, 1957) and, in tropical environments, obligate cross-fertilization has been considered a main strategy in plants (Bawa, 1974, Ruiz and Arroyo, 1978, Sobrevila and Arroyo, 1982, Bawa et al., 1985, Bullock, 1985). The reproductive strategy of a species affects its population size and the distribution of genetic variability within and among populations (Lande 1988, Menges, 1991). Reproductive systems of plants have been identified as the main factor influencing the genetic structure of populations (Loveless and Hamrick, 1984), and are important for systematics (Anderson et al., 2002). The objective of this study was to investigate the reproductive system of $E$. fulva, in relation to other species in the Melastomataceae family, thereby contributing to the understanding of the mechanisms involved in the survival of its populations.

\section{Material and Methods}

\subsection{Study area}

This study was performed in the Jambreiro Forest (912 hectares), in the central-southeast region of Minas
Gerais state, between $19^{\circ} 58^{\prime}-59^{\prime} \mathrm{S}$ and $43^{\circ} 55^{\prime}-52^{\prime} \mathrm{W}$, in the municipality of Nova Lima, in the metropolitan region of Belo Horizonte. The region of Nova Lima is located in the São Francisco basin, in the Quadrilátero Ferrífero (a region with ferruginous ore sites), which is drained from north to south by the river Rio das Velhas and its tributaries (Alves, 1988). The climate is Koeppen's Cwa, macrothermic temperate with mild summers and dry winters. Rains (1400-1600 mm.year ${ }^{-1}$ ) predominate during the hottest period (October to March), the mean annual temperature is $18{ }^{\circ} \mathrm{C}$, mean maximum temperature is $21^{\circ} \mathrm{C}$, and the mean minimum temperature is $14{ }^{\circ} \mathrm{C}$ (Alves, 1988). The soil is dystrophic Cambisol (Cetec, 1983), and the altitude varies between 800 to $1100 \mathrm{~m}$, with an undulating topography. This study was conducted in an area adjacent to the water stream Ribeirão do Cardoso, also named Córrego do Carrapato, at an altitude of $850 \mathrm{~m}$ (Plambel, 1977). The Jambreiro Forest is limited to the north by the Serra do Curral mountains, and by the iron mines of the Minerações Brasileiras Reunidas; and to the southeast by several plots of land and pasture near the city of Nova Lima. The terrain on which the Jambreiro Forest occurs belongs to the company Minerações Brasileiras Reunidas (MBR), and in August 1998 it was protected as a Reserva Particular do Patrimônio Natural (RPPN - private reserve of natural patrimony), a form of land conservation in Brazil.

\subsection{Vegetation}

The local vegetation is montane semideciduous seasonal forest (Veloso et al., 1991), with a canopy of 10-20 m height and some emergent trees. Frequent species are: Sclerolobium rugosum Mart. ex Benth., 1850; Inga luschnathiana Benth., 1845; Croton echinocarpus Baill., 1864 and Anadenanthera colubrina (Vell.) Brenan., 1955; Cecropia pachystachya Trécul., 1847; C. hololeuca Miquel., 1853 and C. glaziovi Snethl., 1923 are also abundant and highly visible, standing out of the overall forest physiognomy (Andrade, 1993).

\subsection{Species studied}

Populations of E. fulva are found in very characteristic habitats, on humid and shaded rocky riverbanks. In the Jambreiro Forest reserve, they are found discontinuously alongside $3 \mathrm{~km}$ on riverbanks of the Carrapato stream, where they do not associate with other species, except for mosses and ferns (personal observation).

E. fulva is a perennial iteroparous species; the young plants are herbaceous rosettes while the adult plants are prostrate, having a single stem, which can reach approximately $70 \mathrm{~cm}$ length (Figure 1). According to Raunkiaer's (1934) plant life form classification, this species can be classified as rosette hemicryptophyte in its young phase and as chamaephyte in its adult phase, with its stem hanging from the rock walls. Leaves are opposite, oval in shape and cordiform at their base, puberulous and with curved veins. Each plant usually displays leaves of many different lengths, and since the plant is fixed by the roots and its stem hangs down from the rock 


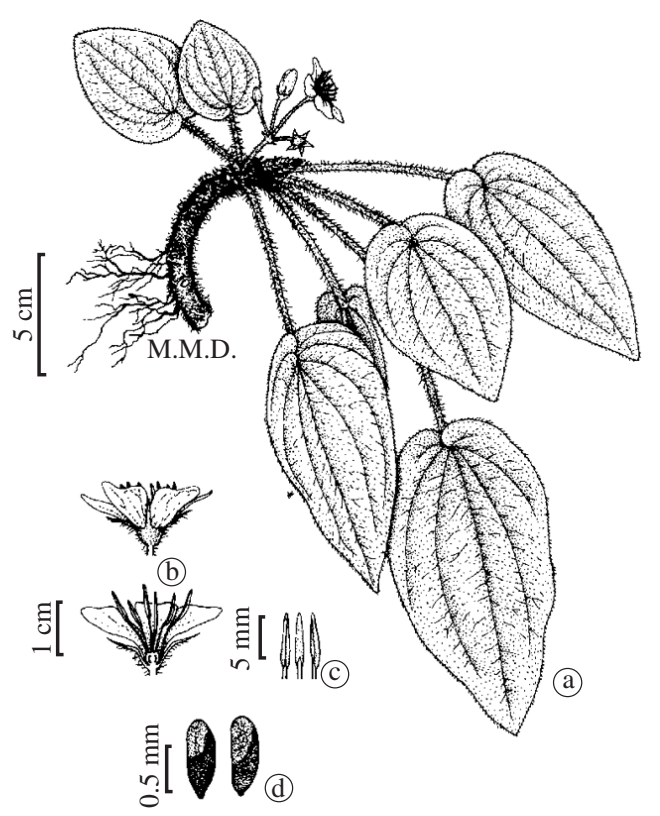

Figure 1. a) E. fulva, reproductive individual with inflorescence, stem and root; b) Flower, longitudinal cut of internal section; c) Stamens; and d) Seeds (the arrow indicates the air pocket).

wall, the smallest and the largest leaves are found on the upper and lower parts of the plant, respectively. While the smallest leaves are erect, the largest leaves hang from the stem with the aid of their long petiole. The number of leaves varies from ten or less to up to around eighty leaves in the largest plants. The petioles are covered with reddish hairs, and range from 0.5 to $30 \mathrm{~cm}$ long. The stem is reddish-brown and densely covered with hairs; it may take the shape of a straight line, like an "I", or may bifurcate at the distal portion, like a "Y." Reproductive individuals may have a stem of variable length, or may not have a stem at all (personal observation).

The fruit is a velatidium capsule, with numerous small (approximately $0.9 \mathrm{~mm}$ in length) tenuously reticulated and shiny seeds (Baumgratz, 1983-1985), which have a translucent structure, resembling an air pocket (personal observation - Figure 1d). Melastomataceae species with capsular fruits are usually dispersed by wind (Renner, 1989).

\subsection{Field methods}

E. fulva was found occurring as groups of plants on rocky walls (phyllite) alongside shaded streams throughout the study site. The reproductive system was investigated through direct observation and experiments (Renner, 1989). The following experiments were performed during the reproductive period of 1997 and repeated during the reproductive period of 1998: a) Spontaneous self-pollination - floral buds were bagged with tulle before anthesis and kept this way until complete flower senescence (falling of petals); b) Self-pollination (auto- gamy) - floral buds were bagged before anthesis and, after anthesis, the stigma received pollen from the same flower; then, flower buds were bagged again until falling of petals; c) Cross-pollination (xenogamy) - floral buds were emasculated and bagged before anthesis and, after anthesis, the stigma received pollen from flowers of different individuals; then, flower buds were bagged again until falling of petals; d) Agamospermy - floral buds were emasculated before anthesis, bagged and not pollinated; they were kept bagged until falling of petals; and e) Control (pollination under natural conditions) - Flowers from several plants were observed without being subjected to any type of treatment. At least 30 flowers were used in each treatment. Flowers in all treatments were marked with colored flagging tape and observed until the fruit was completely developed.

During anthesis, we observed the stigma, checking for visually noticeable changes in order to define the period of receptivity. We recorded the time at which the flower opened and closed, as well as the time interval the flower remained open, the number of flowers opened per day in each plant and the duration of the flowering period of each plant. For manual pollination, pollen was taken from anthers and placed on glass slides onto which the stigma was then rubbed. In order to verify pollen viability, floral buds were collected from 10 different individuals. The buds were fixed in ethanol:acetic acid $\left(3: 1, v^{-1} v^{-1}\right)$ and stored in $70 \%$ alcohol in the freezer. Pollen was inspected under an optical microscope, on a glass slide, onto which one drop of acetic carmine $1.2 \%$ (Medina and Conagin, 1964) was added. In each slide approximately 100 grains of pollen were analyzed, totaling 1000 grains of pollen for all slides. Viable pollen grains displayed well-stained and reddish cytoplasm. This same method was used to determine the number of chromosomes in young floral buds (Medina and Conagin, 1964). The results of the controlled pollination experiments were obtained after one or two months, when fruits were fully developed. Fruit growth was observed monthly in 1998 and 1999 in order to verify the presence of seeds.

In order to identify floral visitors, observations were conducted from 8 to 16 hours, as in Gross (1993), in a total of 60 hours, during the maximum flowering period in 1999 (November-December).

We collected fruits from other populations of the same species, and sent them to the Seção de Sementes of the Instituto Agronômico of Campinas, for seed germination tests. The following treatments were applied: a) constant temperature of $20^{\circ} \mathrm{C}$ under alternate periods of 8 hours light and 16 hours dark; b) dark, with alternating temperatures of $15^{\circ} \mathrm{C}\left(16\right.$ hours) and $20^{\circ} \mathrm{C}$ (8 hours); c) continuous light at $30{ }^{\circ} \mathrm{C}$; d) continuous dark at $30{ }^{\circ} \mathrm{C}$; and e) continuous light at $20{ }^{\circ} \mathrm{C}$. For all treatments two replications of 25 seeds each were used, with the exception of continuous light, which was done with a non-determined amount of seeds. The seeds were put to germinate on two sheets of filter paper moistened with nistatin solution (100 units. $\left.\mathrm{mL}^{-1}\right)$ in Petri dishes. The tests began 
in July 1997 and were concluded in September 1997. Germination tests were also conducted in a greenhouse using organic soil collected nearby in the forest, without controlling light or temperature conditions. To perform the germination tests in the greenhouse we collected fruits in May and September 1999. The number of seeds was counted in six capsules collected from four individuals in August 1999.

\section{Results}

\subsection{Flower characteristics}

The first floral buds appeared at the end of October in both years of observation. The most intense period of flowering lasted for a month, beginning in midNovember and lasting until mid-December in both years of observations. Sparse flowering occurred both before and after this period. The flowering period was relatively long (nearly 45 days).

The inflorescence is a variation of the umbrella type, and is born at the leaf axil. Each inflorescence had from three to 30 flowers, but inflorescences with few flowers were more frequent. Each plant could have three or four inflorescences, but individuals with two or, predominantly, one inflorescence were more common.

The flowers are white with five petals and 10 stamens bearing yellow poricidal anthers; the gynoecium has a long whitish style (Figure 1). The only attraction to visitors is pollen. The anthesis did not present a specific schedule, occurring during the day or night. In each plant one or two flowers opened daily. The duration of a flower, from the beginning of anthesis until complete senescence, represented by the falling of petals, was four days. The mostly likely fertile period was two days. It was not possible to detect the receptivity of the stigma, which is small and punctiform and does not show any visible sign that could be interpreted as indicating receptivity. At the beginning of the anthesis the stamens are folded, and unfold slowly to the end of the anthesis. The complete anthesis, from the beginning of the opening up to the complete unfolding of the stamens, occurred in 24 hours. We observed anthesis occurring in the morning, afternoon and night. Around 96.21 $\pm 3.42 \%$ (mean standard deviation) of the 6,600 grains of pollen examined were viable, thus indicating that the meiotic process occurs regularly. The chromosome number encountered during meiosis was $n=17$ (Figure 2).

\subsection{Reproductive system}

E. fulva has sexual reproduction and is self-compatible (Table 1). Vegetative propagation was not observed. Fruits were not produced in the treatments of agamospermy (emasculated) and spontaneous self-pollination (Table 1). These results show that E. fulva is not apomitic and that spontaneous self-pollination does not occur under natural conditions.

\subsection{Floral visitors}

We witnessed two types of bees visiting flowers. One type was of the genus Trigona while the other, not identified, was $1 \mathrm{~cm}$ length, had a metallic-green abdomen and flew very rapidly. Both species made quick visits. Floral visitors were not present in most of our observations. Stamens were destroyed frequently, possibly by Trigona sp. We also observed predation of the petal edges.

\subsection{Fruits and seeds}

The fruit, a velatidium capsule, is approximately $0.5 \mathrm{~cm}$ length, the number of capsules per plant was $18.46 \pm 17.61$, and the mean number of seeds per capsule was $130.84 \pm 66.82$. We observed that, frequently, the peduncle of the inflorescence and the flower pedicels curved when they dried up and the capsule touched the rocky riverbank. Under these circumstances, when the fruit ripened, the capsule opened and gradually released

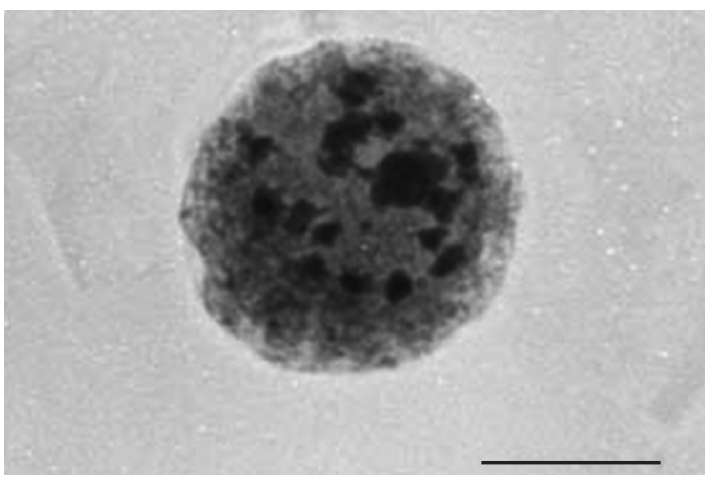

Figure 2. Meiotic cell of E. fulva, in diacinesis, with 17 bivalents. Scale $=5 \mu \mathrm{m}$.

Table 1. Results of controlled pollination experiments in E. fulva during the reproductive periods of 1997 and 1998. $\mathrm{FL}=$ number of flowers, $\mathrm{FR}=$ number of fruits, $\%=$ percentage of fruits produced.

\begin{tabular}{|c|c|c|c|c|c|c|}
\hline \multirow[t]{2}{*}{ Year } & \multicolumn{3}{|c|}{1997} & \multicolumn{3}{|c|}{1998} \\
\hline & FL & FR & $\%$ & FL & FR & $\%$ \\
\hline Emasculation (agamospermy) & 69 & 0 & 0.00 & 48 & 0 & 0.00 \\
\hline Spontaneous Self-pollination & 55 & 0 & 0.00 & 43 & 0 & 0.00 \\
\hline Self Pollination (geitonogamy) & 32 & 4 & 12.50 & 54 & 8 & 14.81 \\
\hline Cross-Pollination (xenogamy) & 38 & 7 & 18.42 & 54 & 23 & 42.59 \\
\hline Natural Conditions & 121 & 31 & 25.61 & 60 & 12 & 20.00 \\
\hline
\end{tabular}


the seeds. Many seeds adhered to the substrate immediately below the capsule, germinated in the place they fell and it was possible to see many seedlings near the parent plant.

In the laboratory, seeds germinated only in the treatment of constant $20^{\circ} \mathrm{C}$ in alternating 8 hours light and 16 hours dark. Fourteen percent of the seeds germinated in this treatment after 30 days. Seeds did not germinate in constant dark or constant light or in higher temperatures. Hence, we may infer that they are positive photoblastic and heat-sensitive. In the greenhouse, seeds from fruits collected in May 1999 germinated after two months; while seeds from fruits collected in September 1999 germinated after 25 days. In this second experiment, $47 \%$ out of the 315 seeds germinated.

Fruits with viable seeds occurred during a long period throughout the year. During the flowering period in December, some fruits with seeds from the last reproductive event were still present. Capsules with seeds were observed on plants even 15 months after fruit ripening.

\section{Discussion}

The flowers of E. fulva may be classified as open (Faegri and Van Der Pijl, 1971), actinomorph, nontubular with reproductive structures in the center. Flowering of this species fits in the steady state pattern (Gentry, 1974), in which the plant has a long flowering period and opens a small number of flowers per day. Pollen is the only attraction to floral visitors, and anthers are poricidal. Melastomataceae flowers that offer only pollen as resource are pollinated exclusively by vibratory bees (Renner, 1989, 1990). Although we had performed 60 hours of observation, the bee with the metallic-green abdomen (probably Hallictidae) was observed on only three occasions. Probably, this is the visitor that vibrates the anthers to remove the pollen, and acts as the pollinator of E. fulva. Trigona bees observed on flowers of $E$. fulva did not enter in contact with the stigma and are incapable of vibrating the anthers, but do pillage pollen (Renner 1983, 1989). We did not observe any insect feeding upon the anthers, yet we frequently found damaged anthers.

E. fulva is self-compatible, a conclusion supported by the formation of fruits in both self- and cross-pollination treatments, but requires specialized pollinators due to buzz pollination syndrome. The null result in the treatment "spontaneous self pollination" confirms the need for a pollinator to fruit set, and agrees with results found in other sexual Melastomataceae species (Renner, 1989). Further studies regarding the pollination biology of $E$. fulva are necessary in order to identify its pollinator.

Fruit set may be influenced not only by the number and efficiency of pollinators but also by the reproductive system of different species. A great variation of fruiting has been observed among different species of Melatomataceae, varying from 8.3 to $90.9 \%$ (Renner, 1986/1987; Gross, 1993; Melo and Machado, 1997; Goldenberg and Shepherd, 1998; Goldenberg and
Varassin, 2001). The low fruit set of E. fulva could be due to failures in the manipulation of flowers or to low availability or efficiency of pollinators. Fruit set in natural conditions was intermediary between that observed in geitonogamy and xenogamy experiments, thus indicating that pollinator availability may be a restraining factor. Since E. fulva has no apomixy and no spontaneous self pollination, its reproduction capacity relies entirely upon pollinators.

The presence of capsules with seeds during long time confirms the pattern observed in other species of this family. The capsules of Melastomataceae are generally robust and remain on the plant for many months during which seeds are gradually released (Renner, 1989). In E. fulva capsules with seeds were observed 15 months after fruit ripening. Seeds are very small and probably could be dispersed by the water stream or by wind. Nearly $40 \%$ of the neotropical Melastomataceae have capsule-type fruits and wind-dispersed seeds (Renner, 1989). However, Melatomataceae tribes with capsular fruits have much more species in savannas than in forests, and zoochory is more efficient than wind in the latter (Renner, 1989).

Long distance dispersal may not be efficient in E. fulva, since the infructescence peduncle and the fruit pedicel bend in such a way that the fruits touch the ground; the seeds are slowly liberated and may germinate nearby. Many seeds of E. fulva adhere to the substrate immediately below the capsule and germinate, thus producing many seedlings near the parent plant, and this suggests a restriction to seed dispersal. We suggest also the possibility of ballistic dispersion by rain drops for E. fulva, as reported for understory herbaceous Melastomataceae species with broadly conic capsules of the tribe Bertolonieae (Renner, 1989).

Both light and temperature are very important to successful seed germination of Melastomataceae in general (Andrade, 1995). The results of the laboratory germination tests were expected according to the environment in which E. fulva populations occur, that is, in humid, shaded rocky riverbanks under the seasonal semideciduous montane forest with mild temperatures. The seeds are heat-sensitive and do not germinate in high temperatures, that is, around $30{ }^{\circ} \mathrm{C}$. They are also positive photoblastic, requiring light to germinate and establish, but requiring also alternation between light and dark periods. This alternation could simulate the conditions of light and shadow in the forest understory. The germination ratio of E. fulva on filter paper in laboratory was small, but it was even smaller (1\%) in Bellucia (Renner, 1986/1987). The germination ratio of E. fulva was greater in the greenhouse on soil from the forest, thus suggesting the need for soil special conditions. E. fulva, like most Melatomataceae species with capsules, has a large number of seeds per capsule. It is possible that this abundance of seeds functions as a compensating mechanism, aiding in the survival of the species by raising 
the chances that more seeds will find suitable habitats (Renner, 1986/1987).

There is little information on chromosome numbers in Melastomataceae as a whole (Renner, 1989). The chromosome number of E. fulva $(\mathrm{n}=17)$ is so far unpublished and certainly will contribute to place the genus in the correct tribe. Eriocnema was initially placed in the Microliceae tribe (Renner, 1989), in which the chromosome numbers are different: $\mathrm{n}=10,11$ or 12 (Almeda 1997). Based on phylogenetic analysis considering morphological and molecular data sets (DNA sequences from the intron of the chloroplast gene rpl16), Fritsch et al. (2004) placed this species in the tribe Miconieae, in which there are several species of Miconia and Clidemia with $n=17$ (Goldenberg and Shepherd 1998).

In plant-pollinator interactions, the distance between neighboring plants seems to be the most important factor for successful pollination (Kunin, 1997). Since E. fulva is self-compatible, the efficiency of cross-pollination may also be determined by the behavior of the pollinator, by the spatial distribution of the individuals within the plant population, and by the number of flowers simultaneously available on each plant. Each E. fulva plant opens only one or two flowers per inflorescence per day, thus the number of flowers available for geitonogamy is small. Moreover, few individuals have more than one inflorescence. Since the daily flower production is low and the flowering is asyncronic among plants, pollinators would visit few flowers in each plant and move intensively between the plants. Therefore, the pollen flow occurs primarily between plants, thus favoring xenogamy (Campbell, 1985) Cross-pollination provides at least two vital advantages: first, the production of new gene combinations, which may help new individuals to cope with varied environments; second, genetic recombination prevent the expression of deleterious genes and enhance survival probability (Proctor et al., 1996). However, to address more fully these issues and their consequences, studies involving the pollen flow between individuals of E. fulva should be performed.

Why may self-compatibility be advantageous to $E$. fulva? The advantages of self-compatibility occur when new populations are formed by only one or a very few individuals (Wells, 1979). In such cases, cross-pollination is impossible, due to the lack of other individuals of the same species in the vicinity. Probably, through selfcompatibility $E$. fulva can obtain higher establishment success alongside streams. At these sites, reproduction would only be possible if pollinators traveled long distances or if plants were self-compatible. Since E. fulva occurs as small discontinuous populations along at least $3 \mathrm{~km}$ on the rocky riverbanks in the study site, self-compatibility may contribute to the establishment of new populations.

Acknowledgments - We are grateful to the National Council of Scientific and Technologic Development (CNPq) for a scholarship awarded to the first author. We thank the Instituto Estadual de Florestas (IEF) for logistical help with the research and Minerações Brasileiras Reunidas for permission to work in the reserve. We thank also Jocely A. Maeda for the seeds germination test.

\section{References}

ALMEDA, F., 1997. Chromosome numbers and their evolutionary significance in some neotropical and paleotropical Melastomataceae. Biollania, Edicíon Esp., no. 6, p. 167-190.

ALVES, WA., 1988. Carta do meio ambiente e sua dinâmica da microbacia do córrego do Cardoso, Nova Lima, MG. Monografia. Belo Horizonte, Instituto de Geociências, UFMG.

ANDERSON, GJ., JOHNSON, SD., NEAL, PR. and BERNARDELLO, G., 2002. Reproductive biology and plant systematics: the growth of a symbiotic association. Taxon., vol. 51 , no. 4 , p. 637-653.

ANDRADE, PM., 1993. Estrutura do estrato herbáceo de trechos da Reserva Biológica Mata do Jambreiro, Nova Lima, $M G$. Tese de Mestrado, Campinas, Instituto de Biologia, UNICAMP.

ANDRADE, ACS., 1995. Efeito da luz e temperatura na germinação de Leandra breviflora Cogn., Tibouchina benthamiana Cogn. Tibouchina grandifolia Cogn. e Tibouchina moricandiana (DC.) Baill. (Melastomataceae). Rev. Bras. Sem., vol. 17 , no. 1 , p. 29-35.

BADINI, J., 1940. Contribuição à geobotanica das Melastomataceas ouropretanas. Rev. Farm. Ouro Preto., Ano I, no. $4-5,8 \mathrm{p}$.

BAUMGRATZ, JFA., 1983-1985. Morfologia dos frutos e sementes de Melastomataceas brasileiras. Arq. Jard. Bot. Rio de Janeiro., vol. 27, p. 113-155.

BAWA, KS., 1974. Breeding systems of tree species of a lowland tropical community. Evolution., vol. 28, no. 1, p. 85-92.

BAWA, KS., PERRY, DR. and BEACH, JH., 1985. Reproductive biology tropical rain forest trees. I. Sexual systems and incompatibility mechanisms. Am. J. Bot., vol. 72, no. 3, p. 331-345.

BORGES, HBN., 1990. Biologia reprodutiva de quatro espécies de Melastomataceae. (Tese de Mestrado) - Campinas. Instituto de Biologia. UNICAMP.

BUCHMANN, SL., 1983. Buzz pollination in angiosperms. In JONES, CE. and LITTLE RJ. (eds.) Handbook of experimental pollination biology. Van Nostrand Reinhold. New York, p. 294-309.

BULLOCK, SH., 1985. Breeding systems in the flora of a tropical deciduous forest. Biotropica., vol. 17, no. 4, p. 287-301.

CAMPBELL, DR., 1985, Pollen and gene dispersal: the influences of competition for pollination. Evolution., vol. 39, no. 2 , p. 418-431.

CETEC, Fundação Centro Tecnológico de Minas Gerais, 1983. Mapa 3/ Solos. Diagnóstico ambiental do estado Minas Gerais. Fundação Centro Tecnológico de Minas Gerais, Comissão de Política Ambiental. Belo Horizonte. MG.

COGNIAUX, A., 1883. Melastomataceae Tribus I Microlicieae Triana. In MARTIUS, CFP. VON, ENDLICHER, S., EICHLER, AG. and URBAN, J. 1860/1906. Flora brasiliensis. Monachii, Lipsiae apud Frid. Fleischer in comm. vol. 14, t. 3. 
COPAM, 1997. Deliberação Conselho Estadual de Política Ambiental (COPAM). Diário do Executivo, Legislativo $e$ Publicações de Terceiros, número 85, de 21 de Outubro de 1997, Minas Gerais, 30.10.1997 Caderno 1, p. 10-12.

FAEGRI, K. and VAN DER PIJL, L., 1971. The principles of pollination ecology. Pergamon Press, New York.

FRITSCH, PW., ALMEDA, F., RENNER, S., MARTINS, AB. and CRUZ, BC., 2004. Phylogeny and circumscription of the near- endemic brazilian tribe Microlicieae (Melastomataceae). Am. J. Bot., vol. 91, no. 7, p. 1105-1114.

FRYXELL, PA., 1957. Mode of reproduction of higher plants. The Bot. Revw., vol. 23, no. 3, p. 135- 233.

GENTRY AH., 1974. Flowering phenology and diversity in tropical Bignoniaceae. Biotropica, vol. 6, no. 1, p. 64-68.

GOLDENBERG, R., 1994. Estudos sobre biologia reprodutiva de espécies de Melastomataceae de cerrado em Itirapina, SP. (Tese de Mestrado) - Campinas. Instituto de Biologia. UNICAMP.

GOLDENBERG, R. and SHEPHERD, GJ., 1998. Studies on the reproductive biology of Melastomataceae in "cerrado" vegetation. Plant Sys. Evol., vol. 211, no. 1-2, p. 13-29.

GOLDENBERG, R. and VARASSIN, IG., 2001. Sistemas reprodutivos de espécies de Melastomataceae da Serra do Japi, São Paulo, Brasil. Rev. Bras. Bot., vol. 24, no. 3, p. 283-288.

GROSS, CL., 1993. The breeding system and pollinators of Melastoma affine (Melastomataceae); a pioneer shrub in tropical Australia. Biotropica, vol. 25, no. 4, p. 468-474.

KUNIN, WE., 1997. Population size and density effects in pollination: pollinator foraging and plant reproductive success in experimental arrays of Brassica kaber. J. Ecol., vol. 85, no. 2, p. 225-234.

LANDE, R., 1988. Genetics and demography in biological conservation. Science. vol. 241, no. 4872, p. 1455-1460.

LOVELESS, MD. and HAMRICK, JL. 1984. Ecological determinants of genetic structure in plant populations. Annиal Review of Ecology and Systematics. vol. 15, p. 65-95.

MEDINA, DM. and CONAGIN, CHTM., 1964. Técnica citológica. Instituto Agronômico. Publicação no 1610 , Campinas.

MELO, GF. andMACHADO, IC., 1997. Auto-incompatibilidade em Miconia ciliata (RICH, LC.) DC. (Melastomataceae). Acta Bot. Bras., vol. 12, no. 2, p. 113-120.

MENGES, ES., 1991. The application of minimum viable population theory to plants. p. 45-61 In FALK, DA. and
HOLSINGER, KE. (eds.) Genetics and conservation of rare plants. Oxford University Press, New York, NY.

PLAMBEL, 1977. Carta de Belo Horizonte. Escala 1:25.000. RMBH 20/32 Folha SE 23-ZC-VI-3-SO Superintendência da Região Metropolitana de Belo Horizonte. Planejamento Região Urbana de Belo Horizonte Convênio PLAMBEL/SECT COPASA/ CETEL/ CEMIG.

PROCTOR, M., YEO, P. and LACK, A., 1996. The natural history of pollination. Harper Collins Publishers, New York.

RAUNKIAER, C., 1934. The life forms of plants and statistical plant geography, being the collected papers of C. Raunkiaer, Clarendon Press, Oxford.

RENNER, SS., 1983. The widespread occurrence of anther destruction by Trigona bees in Melastomataceae. Biotropica, vol. 15 , no. 4, p. 251-256.

-, 1984. Pollination and breeding systems in some central amazonian Melastomataceae. Les Colloques d'INRA, vol. 21, p. $275-280$.

-, 1986/1987. Reproductive biology of bellucia (Melastomataceae). Acta Amazonica 16/17 (número único), p. 197-208.

-, 1989. A survey of reproductive biology in neotropical Melastomataceae and Memecylaceae. Ann. Miss. Bot. Garden, vol. 76 , no. 2 , p. 496-518.

-, 1990. Reproduction and evolution in some genera of neotropical Melastomataceae. Mem. New York Bot. Garden, vol. 55 , p. 143-152.

RUIZ, ZT. and ARROYO, MTK., 1978. Plant reproductive ecology of a secondary tropical deciduous forest in Venezuela. Biotropica, vol. 10, no. 3, p. 221-230.

SOBREVILA, C. and ARROYO, MTK., 1982. Breeding systems in a montane tropical cloud forest in Venezuela. Plant Syst. Evol., vol. 140, no. 1, p. 19-37.

STEIN, BA. and TOBE, H., 1989. Floral nectaries in Melastomataceae and their systematic and evolutionary implications. Ann. Miss. Bot. Garden, vol. 76, no. 2, p. $519-531$.

VELOSO, HP., RANGEL FILHO, ALR. and LIMA, JCA., 1991. Classificação da vegetação brasileira adaptada a um sistema universal. Rio de Janeiro, IBGE. 123p.

VOGEL, ST., 1978. Evolutionary shifts from reward to deception in pollen flowers. In RICHARDS, AJ. (ed.) The pollination of flowers by insects. Academic Press, London, p. 89-96.

WELLS, H., 1979. Self-fertilization: advantageous or deleterious? Evolution, vol. 33, no. 1, p. 252- 255. 
